\title{
Peningkatan Kemampuan Berbahasa Inggris Masyarakat Lokal terhadap Pariwisata Desa Lumban Suhi-Suhi Toruan
}

\author{
Elvita Yenni, Tenerman*, Corry Novrica Ap Sinaga \\ Fakultas Ilmu Sosial Dan Ilmu Politik, Universitas Muhammadiyah Sumatera Utara, Medan, \\ Indonesia \\ *Coresponding Author: tenerman@umsu.ac.id \\ Dikirim: 28-10-2021; Direvisi: 01-11-2021; Diterima: 03-11-2012
}

\begin{abstract}
Abstrak: Pengabdian Kepada Masyarakat ini bertujuan untuk memberikan pelatihan bahasa Inggris bagi pemilik homestay desa Lumban Suhi- suhi Toruan, kabupaten Samosir. Tahapan-tahapan dalam kegiatan ini adalah (1) Tahapan awal, pre-test, (2) Tahapan inti, sosialisasi dan (3) Tahapan akhir, post-test. Kegiatan ini dilakukan untuk membantu meningkatkan kemampuan berbahasa Inggris pemilik homestay desa Lumban Suhi-suhi Toruan Kec. Samosir sehingga mereka memiliki dasar bahasa Inggris yang bermanfaat dalam menyambut wisatawan asing dalam mewujudkan desa Lumban Suhi-Suhi Toruan menjadi desa wisata.
\end{abstract}

Kata Kunci: Homestay; desa wisata; bahasa Inggris

Abstract: This Community Service aims to provide English language training for homestay owners in Lumban Suhisuhi Toruan village, Samosir district. The stages in this activity are (1) the initial stage, pre-test, (2) the core stage, socialization and (3) the final stage, post-test. This activity was carried out to help improve the English language skills of homestay owners in Lumban Suhi-suhi Toruan Kec. Samosir so that they have a basic English language which is useful in welcoming foreign tourists in turning Lumban suhi-suhi Toruan village into a tourist village.

Keywords: Homestay; tourist village; English

\section{PENDAHULUAN}

Kabupaten Samosir di Propinsi Sumatera Utara memiliki kekayaan budaya yang masih kental. Pulau Samosir terkenal akan objek wisata yang dapat dinikmati oleh para wisatawan baik lokal maupun mancanegara. Mayoritas masyarakatnya bersuku Batak. Mereka mendiami kota maupun perkampungan yang ada. Kebudayaan Suku Batak ini, juga menarik untuk dijadikan objek wisata. Banyak desa- desa dikepulauan Samosir merupakan destinasi wisata yang menarik untuk dikunjungi, salah satunya adalah desa pengrajin kain ulos, Lumban Suhi-suhi Toruan.

Lumban Suhi Suhi Toruan adalah salah satu desa yang berada di Kecamatan Pangururan, Kabupaten Samosir. Desa Lumban Suhi-Suhi Toruan. Terletak di antara Pelabuhan Tomok dan Pangururan. Butuh waktu sekitar 40 menit dari Desa Tomok atau 20 menit dari Pangururan melalui jalan darat menuju desa Lumban Suhi-suhi Toruan ini.

Desa Lumban Suhi-suhi Toruan kerap dikunjungi para wisatawan baik asing maupun lokal karena kerajinan kain tenunnya. Ulos adalah kain terun khas Batak berbentuk selendang. Secara harfiah, berarti selimut yang menghangatkan tubuh dan melindunginya dari terpaan udara dingin.Sebagai simbol dari harga diri orang Batak, 
ulos kaya akan motif yang masing-masing memiliki makna dan arti filosofis tersendiri. Ulos yang dihasilkan dari desa ini merupakan hasil kerajinan dari warga setempat yang dikerjakan baik dengan tangan maupun dengan alat tenun.

Beberapa waktu yang lalu Presiden Republik Indonesia, Joko Widodo berkunjung ke desa Lumban Suhi-suhi Toruan. Beliau mengarahkan agar desa tersebut ditata agar menjadi destinasi wisata yang menarik. "Tahun ini dimulai, karena memperbaiki kemudian memindahkan bangunan yang tidak sesuai dengan desa ulos tadi, desa adat tadi, sehingga betul-betul menjadi sebuah tempat tujuan wisata yang menurut saya sangat menarik sekali," kata Presiden Jokowi pada Selasa (Kompas.com, 30/7/2019).

Sebagai destinasi wisata yang telah dicanangkan pemerintah, berbagai hal sedang dilakukan oleh pemerintah desa Lumban Suhi-suhi Toruan. Saat ini pembangunan infrastruktur menjadi fokus utama, seperti pembangunan jalan, homestay dan sebagainya. Selain infrastruktur, tidak terlepas dari sumber daya manusia yang harus di tingkatkan, salah satunya adalah aspek kebahasaan yang merupakan salah satu aspek penunjang tujuan desa wisata seperti yang dirancang oleh pemerintah.

Selain kecakapan bahasa daerah dan bahasa Indonesia masyarakat lokal, bahasa Inggris juga menjadi salah satu komponen terpenting lainnya. Berdasarkan riset awal yang dilakukan peneliti, rata- rata masyarakat lokal belum mampu menggunakan bahasa Inggris dalam percakapan sehari-hari dengan tata bahasa dan kosa kata yang tepat. Bahasa Inggris yang mereka gunakan kebanyakan secara otodidak untuk memenuhi kebutuhan komunikasi disaat-saat tertentu saja. Dalam prakteknya, kegiatan masyarakat lokal desa Lumban suhi-suhi Toruan ini telah mendunia, seperti mereka pernah diundang ke Eropa beberapa tahun yang lalu untuk mengadakan pameran kebudayaan batak. Hal ini menjadi menarik bagi peneliti untuk memberikan pelatihan berkaitan dengan kebutuhan berbicara sehari-hari (daily conversation) dengan wisatawan mancanegara bagi masyarakat lokal dan berbagi ilmu tentang cara mendeskripsikan tempat wisata, potensi wisata, dan segala informasi wisata (describing place) di desa Lumban Suhi-suhi Toruan dalam bahasa Inggris.

Permasalahan masyarakat lokal desa Lumban Suhi-suhi Toruan dari sisi kebahasaan adalah pertama, minimnya kegiatan-kegiatan berbasis peningkatan kemampuan berbahasa mencakup kemampuan berbicara dan berkomunikasi yang baik dalam berbagai bahasa, yaitu bahasa lokal, bahasa Indonesia dan bahasa Inggris. Kesiapan masyarakat lokal menuju desa wisata sangat membutuhkan aspek kecakapan berbahasa setidaknya menguasai dalam satu rumpun bahasa sangat membantu tercapainya cita-cita desa wisata ini. Kedua, Masyarakat lokal belum menyadari pentingnya untuk meningkatkan kemampuan berbahasa, terutama berbahasa Inggris. Ketiga, kurangnya fasilitas pendidikan bahasa Inggris di desa Lumban Suhi- suhi Toruan.

Desa wisata Lumban Suhi- suhi Toruan sebelum dicanangkan menjadi desa wisata telah pun dikenal wisatawan lokal dan mancanegara. Permasalahan yang ditemukan dari sisi kebahasaan perlu untuk disikapi oleh pemerintahan desa mitra tersebut. Pemerintahan desa sebagai fasilitator kegiatan diharapkan mampu mendukung program kemitraan masyarakat ini sebagai langkah awal persiapan menyongsong desa wisata Lumban suhi-suhi Toruan. 


\section{METODE PELAKSANAAN KEGIATAN}

Tahapan pelaksanaan program kemitraan bagi masyarakat ini akan dilaksanakan dengan dalam 3 tahapan yaitu: Tahapan awal dari kegiatan ini adalah sosialisasi tentang tujuan kegiatan dan proses pelaksanaan pelatihan yang akan mereka ikuti. Pada tahap ini juga akan dilakukan pengamatan awal tentang rata- rata kemampuan peserta dalam berbahasa Inggris dengan bentuk kegiatannya akan berupa tahapan perkenalan antara peserta dan instruktur, dan antara satu peserta dengan peserta lainnya. Setelah itu tim peneliti membagikan kertas untuk tes awal (Pre-test) kepada peserta berupa pertanyaan dalam bahasa Inggris sesuai dengan topik sekitar 30-45 menit.

Tahapan inti dilaksanakan beberapa tahap, pertama;memberikan contohcontoh percakapan dalam bahasa Inggris dengan topik yang berkaitan dengan pariwisata, khususny bertanya tentang arah dan tempat, mempraktekkan, memberikan feedback. Kedua; sosialisasi teknik mendeskripsikan tempat wisata dalam bahasa Inggris serta mempraktekkan dan memberi feedback pada peserta. Peserta diminta untuk membuat percakapan singkat tentang arah dan tempat dalam bahasa Inggris secara berpasangan dan membuat tulisan deskripsi singkat tempat wisata, potensi wisata, dan sebagainya yang ada di desa Lumban Suhi-Suhi Toruan, yang mereka pilih sendiri.

Tahapan akhir dengan menguji peserta tentang pemahaman dan keterampilan yang telah diberikan dengan membagikan kertas pertanyaan saat tes- awal. Dalam hal ini instruktur menilai dari berbagai aspek mulai dari adakah perubahan isian pertanyaan setelah dilakukan pelatihan singkat dan adakah peningkatan kemampuan dalam berbicara bahasa Inggris sehari-hari tentang arah dan tempat serta adakah peningkatan dalam mendeskripsikan tempat dalam bahasa Inggris. Dan diakhir tahapan ini, instruktur dan tim memilih 3 peserta untuk coba mempresentasikan percakapan bahasa Inggris yang telah mereka kerjakan.

\section{IMPLEMENTASI KEGIATAN DAN PEMBAHASAN}

Program kemitraan masyarakat ini diawali dari tahap berkordinasi mulai dari tim pelaksana, LP2M UMSU sampai kepada mitra. Pada tahap ini anggota tim mengadakan kordinasi dengan mitra berkaitan dengan jadwal kegiatan, tempat penyelenggaraan, dan agenda kegiatan.

Sesuai dengan permasalahan yang dihadapi mitra Program kemitraan masyarakat ini dilakukan dalam bentuk transfer iptek yang dilakukan berupa sosialisasi, pelatihan dan pendampingan kepada mitra. Pelaksanaan kegiatan ini bertepatan pada tanggal 09 Juli 2021 berlokasi di kantor Desa Lumban Suhisuhi Toruan Kabupaten Samosir mulai dari pukul 08.30-11.00.

Kegiatan diawali dengan Perwakilan Kepala Desa Lumban Suhi-Suhi Toruan memperkenalkan tim dosen kepada peserta, para pemilik homestay. Beliau menyampaikan maksud dan tujuan tim dosen, walaupun sebelumnya mereka telah diberitahu.

Selanjutnya, tim memulai pelaksanaan kegiatan dengan tahapan pertama penguatan pada maksud dan tujuan kegiatan. Kemudian tim membagikan daftar pertanyaan dalam bahsa Inggris sebanyak 5 pertanyaan sebagai bentuk pre-test awal kegiatan, tahap selanjutnya mensosialisasikan bahan yang telah disusun oleh tim 
kepada peserta. Peserta menyimak materi yang telah berada ditangan mereka. Selanjutnya, tahapan tindakan atau action dilakukan dalam bentuk diskusi dan tanya jawab serta memberikan pelatihan singkat bagaimana meningkatkan pemahaman dan keterampilan masyarakat lokal dalam menunjukkan arah tempat secara sederhana dalam bahasa Inggris dan bagaimana meningkatkan pemahaman dan keterampilan masyarakat lokal dalam mendeskripsikan tempat wisata juga dilatih. Kegiatan diakhiri dengan post-test.

Tahapan evaluasi berkaitan dengan mengadakan post- test yaitu dengan cara membagikan lagi daftar pertanyaan dengan pertanyaan yang sama untuk mengetahui tingkat kemampuan dan keterampilan peserta, serta meminta perwakilan peserta yang telah menyiapkan tulisan mendeskripsikan tempat dalam bahasa Inggris untuk membaca kedepan hasilnya sebagai bahan perbandingan dari pre- test sebelumnya. Hasil pre-test dan post test berada dilampiran.

Pada paparan hasil program kemitraan masyarakat terlihat adanya peningkatan pengetahuan peserta dalam hal ini pemilik homestay didesa Lumban Suhi-suhi Toruan walaupun peningkatan kemampuan yang tidak terlalu banyak dari sebelumnya karena beberapa faktor yang terjadi, yaitu karena keterbatasan waktu pelatihan dan minimnya kemampuan dasar berbahasa Inggris para peserta. Hal ini sesuai dengan target luaran yang ingin dicapai yaitu meningkatkan pemahaman dan keterampilan pemilik homestay didesa Lumban Suhisuhi Toruan dalam berbahasa Inggris yang nantinya berguna bagi keberlangsungan homestay yang mereka kelola.

Dari 10 peserta pemilik homestay, secara keseluruhan terlihat dari hasil pretest dan post-test bahwa rata-rata mereka tidak memiliki kemampuan dasar berbahasa Inggris. Terdapat 4 orang yang murni menjawab pre-test dan post-test dalam bahasa Indonesia. Artinya pelatihan 2,5 jam belum berdampak bagi mereka, sementara 5 orang telah mengalami peningkatan kemampuan dari tidak tahu menjadi sedikit tahu. Mereka berusaha dari menjawab pre-test berbahasa Indonesia menjadi sedikit berbahasa Inggris. 1 orang peserta faham berbahasa Inggris dari pre test sampai posttest.

\section{KESIMPULAN}

Dari hasil dan pelaksanaan kegiatan PKM pelatihan peningkatan kemampuan berbahasa Inggris di desa Lumban Suhi-suhi Toruan, Samosir dapat disimpulkan bahwa PKM ini diselenggarakan dengan baik dan berjalan dengan lancar sesuai dengan rencana kegiatan yang telah disusun meskipun belum semua peserta pendampingan menguasai dengan baik materi yang disampaikan. Kegiatan ini mendapat sambutan sangat baik terbukti dengan keaktifan peserta mengikuti pendampingan dengan tidak meninggalkan tempat sebelum waktu pelatihan berakhir. Berdasarkan evaluasi yang telah dilakukan disarankan adanya kegiatan lanjutan yang berupa pelatihan sejenis untuk diselenggarakan secara periodik sehinga dapat mengenalkan bahasa Inggris dan dapat meningkatkan kemampuan masyarakat desa lumban suhi-suhi Toruan.

\section{DAFTAR PUSTAKA}

Azar, Betty Schramfer. (2006). Basic English Grammar. Third Edition. New York: Longman 
Azar, Betty Schramfer. (2006). Understanding and Using English Grammar. Third Edition. New York: Longman

Long J.C Richard. (1995). Breakthrough 1. New Edition. Oxford University Press.

Long J.C Richard. (1995). Breakthrough 2. New Edition. Oxford University Press.

Mark Hancock \& Annie Mc Donald. (2013). English Result Pre- Intermediate. Oxford University Press

Sirait, CharlesBonar. (2012), "Public Speaking for Teacher, Kiat Sukses Pendidik Berkomuni kasi dengan Publik", Cetakan 1, Grasindo, Jakarta.

Tillitt, B and Bruder, Mary Newton. Speaking Naturally. Cambridge University Press.

https://regional.kompas.com/read/2019/07/31/16120531/jokowi-minta-kampungulos-di-samosir-ditata-jadi-destinasi-wisata. Diakses tanggal 14 Februari 2021 